\title{
هل تركيبة مجلس الإدارة والملكية تخفض تكاليف الوكالة: حالة من الثركات المساهمة السعودية
}

\author{
سالم علي الغامدي \\ قسم الدحاسبة - جامعة الطائف
}

المستخلص: تهدف هذه الدراسة إلى كثف النقاب عن أثر تركيبة مجلس الإدارة وهيكل الملكية على تخفيض تكاليف

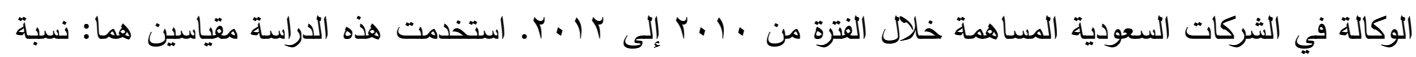

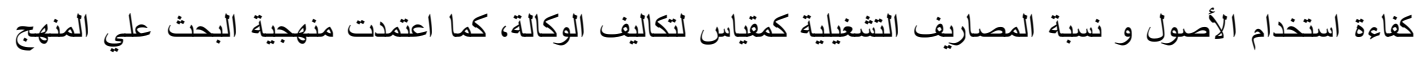

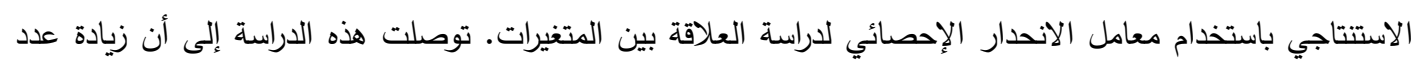

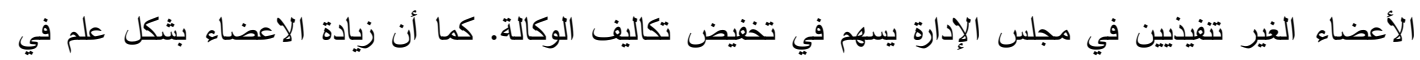
مجلس الادارة ولجنة المراجعة يؤدي ايضاً الى تخفيض تكاليف الوكالة، بينما اجتماعات مجلس الإدارة ووجود الخبير

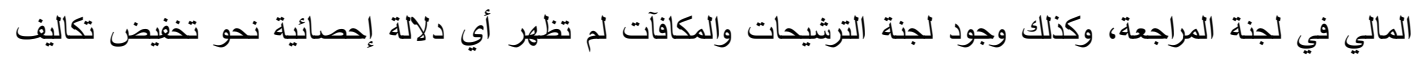

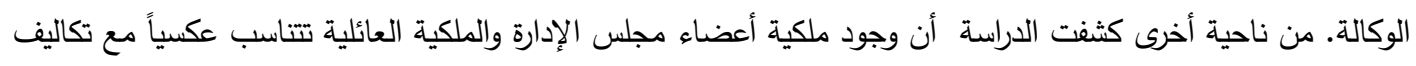

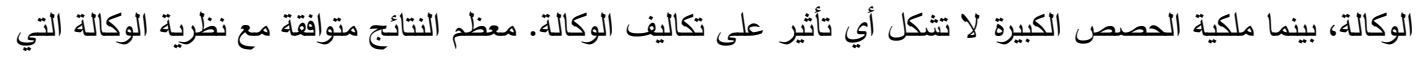

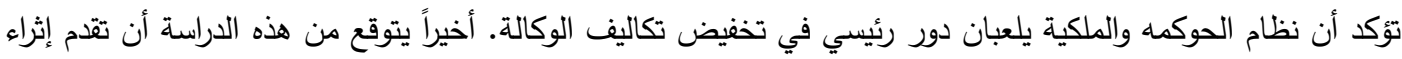

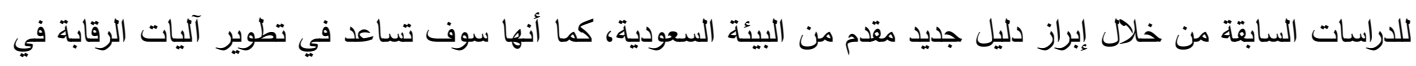
المملكة العربية السعودية وكذلك تخفيض تكاليف الوكالة بشكل خاص. 
International Journal of Managerial Finance, Vol. 4 No. 1, pp. 37-59.

Gogineni, S., Linn, S., Yadav, P. (2010). Empirical Evidence on Ownership Structure, Management Control and Agency Costs. Working Paper. Available in SSRN.

Gujarati, D.N. \& Porter, D.C. (2009) Basic Econometrics, Boston, McGraw-Hill.

Gul., Sajid, Sajid., Muhammad, Razzaq., Nasir, Afzal., Farman., (2012). Agency Cost, Corporate Governance and Ownership Structure (Case of Pakistan). International Journal of Business and Social Science. Vol. 3 No. 9; Pp. 268-278.

Habbash, M. (2010). The Effectiveness of Corporate Governance and External Audit on Constraining Earnings Management Practices in the UK. Unpublished PhD. Durham University, Business School.

Henry, D. (2010). Agency Costs, Ownership Structure and Corporate Governance Compliance: A Private Contracting Perspective. Pacific-Basin Finance Journal. Vol.18.No.1.Pp: 24-46.

Henry, D., (2004). Corporate Governance and Ownership Structure of Target Companies and the Outcome of Takeover Bids', Pacific-Basin Finance Journal. 12: 419-444.

Hermalin, B. E. and Weisbach, M.S. (1991). The Effects of Board Composition and Direct Incentives on Firm Performance. Financial Management. 21: 101-112.

Holderness, C., (2007). The Myth of Diffuse Ownership in the United States, Review of Financial Studies.

Hoque, Z.M. (2006). Methodological Issues in Accounting Research: Theories and Methods. Spiramus Press Ltd. Australia.

Ibrahim., H. and Abdul Samad, F. (2011). Corporate Governance and Agency Cost: Evidence from Public Listed Family Firms In Malaysia. International Corporate Governance. Vol. 14, Pp.109-130.

Jensen, M. C. (1986). Agency Costs of Free Cash Flow, Corporate Finance and Takeovers. American Economics Review, Vol. 76, Pp. 323-339.

Jensen. M. and Meckling, W. (1976). Theory of the firm: Managerial Behavior, Agency Costs and Ownership Structure. Journal of Financial Economics, Vol. 3, No. 4. Pp: 305-360.

Klein, A. (2000). CEO Power, Board Independence and CEO Compensation: An Empirical Investigation. Working Paper, New York University.

Lemmon, M., and Lins, K. V. (2001). Ownership Structure, Corporate Governance, and Firm Value: Evidence from the East Asian Financial Crisis. Journal of Finance, 58(4), 14451468.

Leuz, C., Nanda, D. and Wysocki, P. D. (2003). Earnings Management and Investor Protection: An International Comparison, Journal of Financial Economics. Vol. 69. PP: 505-527.

Lin, J. and Hwang, M. (2010). Audit Quality, Corporate Governance, and Earnings Management: A Meta-Analysis. International Journal of Auditing. Vol.10.Pp.1099-1123.

MacMillan, K. and Downing, S. (1999). Governance and Performance: Goodwill Hunting. Journal of General Management, 24(3), 11-21.
McGee, R.W. (2010). Corporate Governance in Developing Economies. first version, Springer, Science and Business Media.

McKnight, P. and Weir, C. (2009). Agency Costs, Corporate Governance Mechanisms and Ownership Structure in Large UK Publicly Quoted Companies: A Panel Data Analysis. The Quarterly Review of Economics and Finance. Vol. 49.Pp. 139158.

McKnight, P.J. and Mira, S. (2003). Corporate Governance Mechanisms, Agency Costs and Firm Performance in UK Firms, http://ssrn.com/abstract $=460300$.

Pagano, M. and Roell, A. (1998). The Choice of Stock Ownership Structure: Agency Cost, Monitoring, and the Decision to Go Public. The Quarterly Journal of Economics: No.34.

Pearce, J.A. and Zahra, S.A. (1991). The Relative Power of CEOs and Boards of Directors: Association with Corporate Governance, Strategic Management Journal. 12: 135-18.

Phillip. J. and Weir, C. (2009). Agency Costs, Corporate Governance Mechanisms and Ownership Structure in Large UK Publicly Quoted Companies: A Panel Data Analysis. The Quarterly Review of Economics and Finance. Vol.49 Pp. 139158.

Sarkar, J., Sarkar, S. and Sen, K. (2006). Board of Directors and Opportunistic Earnings Management: Evidence from India. Journal of Accounting, Auditing \& Finance, Pp.518-550.

Shapiro, S.,(2005). Agency Theory. Rev. Social, Vol. 31, Pp: 263-283.

Shleifer, A. and Vishny, R. (1997). A Survey of Corporate Governance." Journal of Finance 52 (2).Pp: 737-83.

Singh, M. and Davidson III, W.N. (2003). Agency Costs, Ownership Structure and Corporate Governance Mechanisms, Journal of Banking and Finance. 27: 793-816.

Uzun, H., Szewczyk, S.H. and Varma, R. (2004). Board Composition and Corporate Fraud. Financial Analysts Journal, 60, 3; ABI/INFORM Global.

Wellalage., N.H. and Locke., S. (2011). Agency Costs, Ownership Structure and Corporate Governance Mechanisms: A Case Study in New Zealand Unlisted Small Companies. International Research Journal of Finance and Economics. No.87. Pp. 1450-2887.

Westphal, J. and Zaiac, E. (1995). Who Shall Govern? CEO/Board Power, Demographic Similarity, and New Director Selection, Administrative Science Quarterly. 40: 60-83.

Woodward, S and Alchian, A.A. (1988). The Firm is Dead: Long Live the Firm A Review of Oliver E.Williamson's The Economic Institutions of Capitalism, Journal of Economic Literature 26(1).

Xie, B., Davvidson, W.N III and DaDalt, P.J.,(2003). Earnings Management and Corporate Governance: the Role of Board and Audit Committee, Corporate Finance, Vol.9.

Yatim, P., Kent, P. and Clarkson, P. (2006). Governance Structures, Ethnicity and Audit Fees of Malaysian Listed Firms, Managerial Auditing Journal. 21(7): 757-82. 
enhance the understanding of ownership structure, future studies need to investigate the relationship between agency cost and certain other types of structure of ownership such as state-owned and institutional ownership, and differentiate between family and non-family ownership. Moreover, other proxies for agency cost could be used, such as growth opportunities measured by Tobin's- $Q$ defined as market capitalization plus total debt divided by total assets and the number of acquisitions undertaken each year by a firm. Researchers need to extend the investigation of this paper by studying the relationship between nonlinear ownership and agency cost. Finally, there is a need for more research to cover the financial and insurance sectors which have different accounting practices, involving more years of data, and adding some control variables in order to more be effective.

\section{Acknowledgements}

This paper has benefited from helpful comments and suggestions from anonymous professors in financial accounting. I also gratefully acknowledge financial support from Taif University and Saudi firms for their help and support.

\section{References}

Abdul Rahman, R. and Ali, F.H. (2006).. Board, Audit Committee, Culture and Earnings Management. Managerial Auditing Journal, Vol.21, No.7: Pp.783-804.

Adams, R., Hermalin, B. and Weisbach, M. (2009). The Role of Boards of Directors in Corporate Governance: Conceptual Framework and Survey. Journal of Economic Literature, Vol. 22, No. 1, Pp: 20-47.

Agrawal, A. and Knoeber, C.R. (1996). Firm Performance and Mechanisms to Control Agency Problems between Managers and Shareholders, Journal of Financial and Quantitative Analysis. 31: 377-397.

Alghamdi, S.A. (2001). Investigation into Earnings Management Practices and the Role of Corporate Governance and External Audit in Emerging Market: Empirical Evidence from Saudi Arabia. Unpublished thesis, Durham University, UK.

Anderson, D., Sweeney, D. and Williams, T. (2011). Statistics for Business and Economics (1 $1{ }^{\text {th }}$ ed). South-Western, a Part of Cengage Learning. Canada.
Ang, J.S., Cole, R.A. and Wuh Lin, J. (2000). Agency Costs and Ownership structure, Journal of Finance. 55: 81- 106.

Bedard, J., Marrakchi, S. and Chouteau, L. (2004). The Effect of Audit Committee Expertise, Independence, and Activity on Aggressive Earnings Management. Auditing: A Journal of Practice \& Theory, Vol. 23 No.2. Pp:13-36.

Bhagat, S., and Black, B. (2002). The Non-correlation between Board Independence and Long-term Firm Performance. Journal of Corporation Law, Vol. 27, No. 2: pp. 231-273.

Boone, A., Field, L., Karpoff, J., \& Raheja, C. (2007). The determinants of corporate board size and composition: An empirical analysis. Journal of Financial Economics, 85, 66101.

Brickley, J., Lease, R.C., and Smith, C.W. (1988). Ownership Structure and Voting on Antitakeover Amendments Journal of Financial Economics. 20: 267-291.

Byrd, J. W., and Hickman, K.A. (1992). Do Outside Directors Monitor Managers? Journal of financial Economics. 32: 195221.

Campbell, T.L., and Keys, P.Y. (2002). Corporate Governance in South Korea: The Chaebol Experience. Journal of Corporate Finance, 8(4), 373-391.

Carcello, J.V., Hollingsworth, C.W., Klein, A. and Neal, T.L. (2006). Audit Committee Financial Expertise, Competing Corporate Governance Mechanisms, and Earnings Management. SSRN Working paper.

Clark, T., (2004). Theories of Corporate Governance, Rev.Sociol, Vol. 31. Pp.263-283.

Coles, J., Lemmon, M. and Mescke, J. (2005). Structural models and endogeneity in corporate finance: The link between managerial ownership and corporate performance. Working Paper, Arizona State University.

Cooper, D. R. and Schindler, P.S. (2001). Business Research Method (7th ed.). Singapore: Irwin/ McGraw Hill Publication.

Core, J., Holthausen, R. and Larcker, D., (1999). Corporate Governance, Chief Executive Compensation, and Firm Performance. Journal of Financial Economics. Vol. 51, Pp. 371-406.

Davidson, R., Goodwin-Stewart, J. and Kent, P. (2005). Internal Governance Structures and Earnings Management. Accounting and Finance, Vol. 45. Pp: 241-267.

Deegan, C., Rankin, M. and Voght, p. C. (2000). Firms Disclosure Reactions to Major Social Incidents: Australian Evidence: Accounting Forum. 24 (1).Pp:.312-343.

Denis, D.J., Denis, D.K., and Sarin, A. (1997). Agency Problems, Equity Ownership, and Corporate Diversification. Journal of Finance. 52.Pp: 135-160.

Depken, C., Nguyen, G. and Sarkar, S., (2006), Agency Theory, Executive Compensation, Bonding and Monitoring: A Stochastic Frontier Approach. Corporate Governance. Working Paper University of Texas at Arlington.

Fama, E. and Jensen, M.C. (1983). Separation of Ownership and Control. Journal of Law and Economics, Vol. 26. Pp: 30125.

Florackis, C. and Ozkan A. (2004). Agency Costs and Corporate Governance Mechanisms: Evidence for UK Firms, Working Paper, University of York, UK.

Florackis, C., (2008). International Journal of Managerial Finance Emerald Article: Agency Costs and Corporate Governance Mechanisms: Evidence for UK Firms. 
agency costs. The results therefore provide an overview of the usefulness of a governance system that should result in companies having similar structures.

By using different measurements of agency cost, it is found that Saudi companies have moved to new and topical structures that are fairly consistent with value maximization and slightly reducing agency cost in recent years. For example, Alghamdi (2012), using data collected from the Saudi market between 2006 and 2009, found governance system has no effect on residual cost which is a type of agency cost and explains this finding by the fact that governance system was still new and needed more time to be effective. This reinforces the theoretical framework, presented by previous studies such as McKnight and Weir (2009) and Boone et al. (2007) that there is a range of board structures that are consistent with valuemaximisation and that adopting the Combined Code has brought about little change in the effectiveness of governance structures. Thus, these findings show that the increasing adoption of recommended governance structures provides shareholders with fewer information asymmetry issues. Evidence of increasing compliance seems to be consistent with good governance system.

This study has attempted to examine the role of board characteristics and ownership structure in mitigating agency cost. During the period 2010 to 2012, this study selected firms listed on the Saudi stock Exchange employing non-probability sampling by using the judgment method to select sample members to fit certain criteria. Asset utilization (AC1) and expenses ratio (AC2) are used as proxy for agency cost. Random fixed effect regression is also used to analyze the data. Independent variables consist of governance and ownership related attributes such as board size, number of board meetings, outside directors, audit committee size, financial expertise, nomination and remuneration committees, board ownership, family ownership, and blockholder ownership.

The regression analysis provides evidence that, with exception of financial expertise at audit committee, board meetings, and nomination and remuneration committee, governance system was found to be slightly effective in reducing agency cost. There is also reasonable evidence that higher ownership reduces agency. In other words, this study finds board ownership and family ownership to be effective in reducing agency cost. This finding is consistent with agency theory that beneficial governance system and concentrated ownership might mitigate agency problems leading to reduced agency cost by aligning the interests of controlling owners with those of the company (Jensen and Meckling, 1976)

Notwithstanding the findings, the current study does have limitations, which point to potentially fruitful further research opportunities. First, the study only covers data of firms that are listed on the Saudi stock exchange. Second, this study does not cover financial and insurance firms because they have different accounting practices. Third, since the research involves a single country, the findings may not be generalisable. Fourth, one of the greatest challenges of a study of governance in Saudi Arabia is the difficulty in obtaining relevant and valuable information. Finally, although, Coles et al. (2008) argue that "firmlevel governance must therefore be treated as endogenous; if it is not, we are estimating a reduced form model rather than a structural one", this study does not take endogeneity in consideration

These findings could be helpful for Saudi regulators and Saudi firms in their attempts to enhance the quality of monitoring mechanisms and reduce agency cost.

\subsection{Suggested Future Research}

Due to the limitations and findings of the current study, a number of areas for further study have been identified. Firstly, in order to 
committees might be responsible for alleviating the agency problem between the firm and the outside shareholders by monitoring its financial reporting (Xie et al., 2003). Financial expertise is found not to be effective in reducing agency cost in both models. This is not surprising since, regarding the data collected from the 97 top firms for the two years 2002-2003, Abdul Rahman and Ali (2006) provide insufficient evidence to support the claim that the presence of financial experts on audit committees mitigates residual costs.

Although the nomination and remuneration committee's role is to ensure that director appointments, whether executive or nonexecutive, are made on merit rather than by patronage, multivariate analysis shows a statistically insignificant relationship between the existence of a nomination and remuneration committee and assets utilisation ratio and expenses ratio. The presence of such a committee is found not to be effective in mitigating agency cost. The justification for the negative finding could be that the nomination and remuneration committee is still a new concept in Saudi companies in comparison with the audit committee which has been established for long time, and may need more time to become effective.

In terms of ownership structure, the result also indicates that a high level of director ownership contributes to reducing agency cost in the Saudi market. As shown in Table (4) director ownership has a positive influence on asset utilisation ratio and is negatively related to expenses ratio. This is not surprising since director ownership plays a significant role in decision-making and a firm's performance, resulting in mitigation of agency cost. This finding is consistent with Gul et al. (2012) and Mustapha and Ahmed (2001) but, is contrary to the results provided by Singh and Davidson III (2003) who conclude that director ownership has a negative association with asset utilisation ratio. Hence, the hypothesis which assumes that higher director ownership should reduce agency cost is accepted.

As shown in Table (4), family ownership is found to be negative and significant with expense ratio, but insignificant with utilisation ratio, because most small- and medium-scale enterprises are managed by a founder sitting on the board and managing activities related to trading and manufacturing. Moreover, family ownership can alleviate agency cost by increasing the number of directors and adopting the role of duality. The result is consistent with Ibrahim and Abdul Samad (2011) who find that family ownership affects agency cost. Thus, the hypothesis which assumes that higher family ownership should reduce agency cost is accepted. However, blockholder ownership does not have a significant effect on agency cost. A similar result was concluded by Darren Henry (2006) while taking asset utilization ratio as the dependent variable. Singh and Davidson III (2003) also show there to be no significant impact on agency cost when it is measured in terms of discretionary expense ratio and asset utilization ratio.

The coefficients for the control variable firm size, is positively significant with utilisation ratio but is not significant with expense ratio. In other words, this study concludes that a large firm can manage and control agency costs better than a small firm. This finding is consistent with Woodward and Alchian (1988) who looked at 500 firms and concluded that company size is negatively associated with the agency cost of the company. Conversely, leverage has no effect on either model whether with utilisation ratio or expense ratio.

\section{Summary, Conclusion and Limitations}

In Saudi Arabia, listed firms are expected to 'comply or explain' their board structures by a Combined Code of best practice. The data show that Saudi firms are moving towards compliance and hence the panel nature of the data can identify how this movement mitigates 


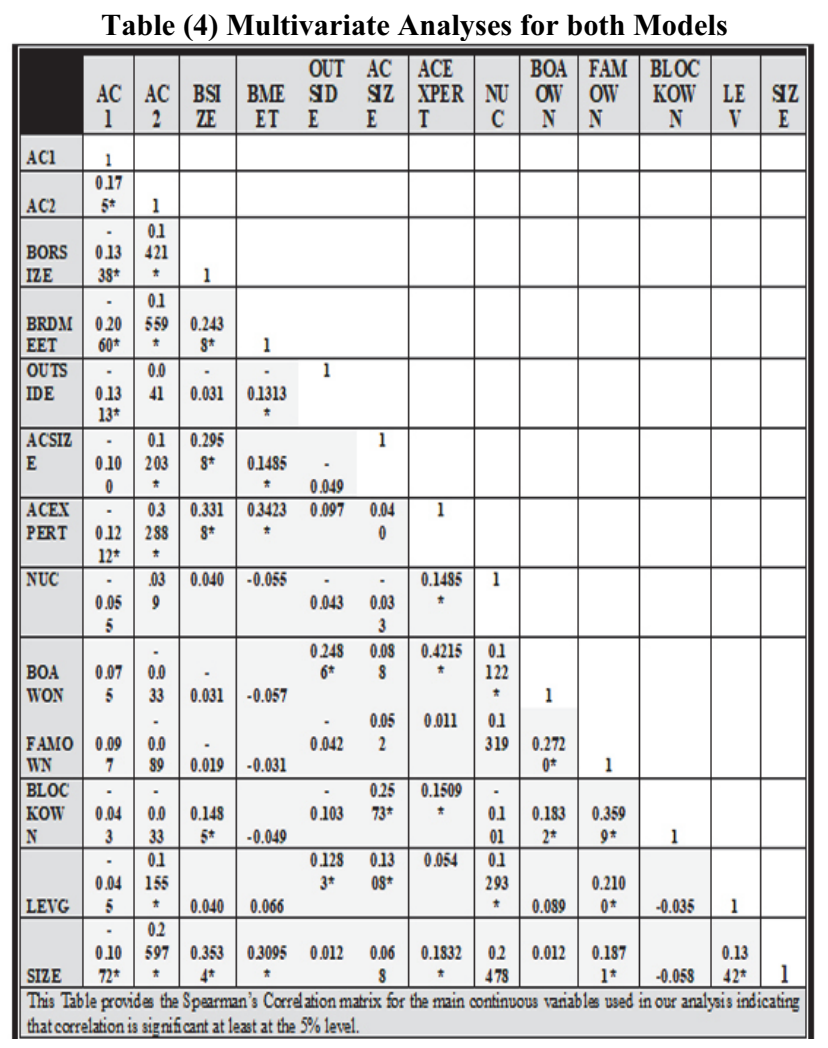

The ACI model shows that board size has a significant effect on agency cost, whereas AC2 shows no effect. This is consistent with the common argument that small boards were found less powerful and effective than large boards (Pearce and Zahra, 1991). This result is also supported by Ibrahim and Abdul Samad (2011) and Singh and Davidson III (2003) who state that the association between size of board and asset utilization ratio is positive and statistically significant. However, the result goes against the findings of Florackis (2003) who found that board size is less efficient in asset utilization. This may be because in his study in UK the mean of board size is found to be six directors, whereas the mean board size in Saudi is eight as shown in Table (2). Thus, having more directors on the board increases diversity and efficiency. In contrast, the number of times a board meets as proxy for the board's diligence has no influence on agency cost as shown in both models. This result is not consistent with the common view that directors on boards that meet frequently are more likely to discharge their duties in line with shareholders' interests since more time can be devoted to controlling issues such as agency cost (Gul et al., 2012). Habbash (2010) justifies his finding by stating that frequent meetings may not always be a characteristic of an active board of directors. Adams et al. (2009) carried out an extensive survey to determine the roles of outside directors as advisors and monitors of management. He claims that directors who mainly control management perceive that they participate less in boardroom discussions than other directors and that the CEO often asks them for advice.

The association of audit committee size with asset utilization ratio is statistically significant as shown in Table (4) however, when it measures agency cost as expense ratio the result becomes insignificant. This finding is consistent with the main argument that audit 
method, and does not require the measurement of data.

Accordingly, GLS estimation (random effect) panel regression over the three-year test period was used in this study. This method allowed the study to test for variations among cross-sectional units simultaneously with variations within individual units over time (Anderson et al, 2011). It is worth noting that the current study used stepwise forward regression (Gujarati and Porter, 2009), commonly employed to determine the appropriate model by eliminating variables conceived to enhance the value of $R^{2}$,

\subsection{Multivariate analysis}

As an extension of the correlation analysis performed earlier, a multiple regression analysis is used to gauge the explanatory power of the independent variables against agency cost. Based on the statistical analysis shown in Table (4), the adjusted $R^{2}$ values for the two models are 0.47 and 0.44 respectively, similar to previous studies such as Gul et al. (2012) and Wellalage and Locke (2011). According to the first hypothesis, assuming that agency costs should be lower when companies have a higher percentage of outside directors on the board, both models reveal that there is a strong positive relationship between outside directors and asset utilisation as proxy for agency cost. This means that a higher percentage of outside directors on the board leads to decreased agency cost. Similar findings were found by Gul et al. (2012), Henry, (2004), and Mcknight and Mira 2003) suggesting that agency costs will be lower when companies have a higher number of outside directors on the board. Hence, the hypothesis which assumes that a higher percentage of outside directors on the board should reduce agency cost is accepted.

Table (3) Correlation analysis of variables * denotes significance at the 0.05 level

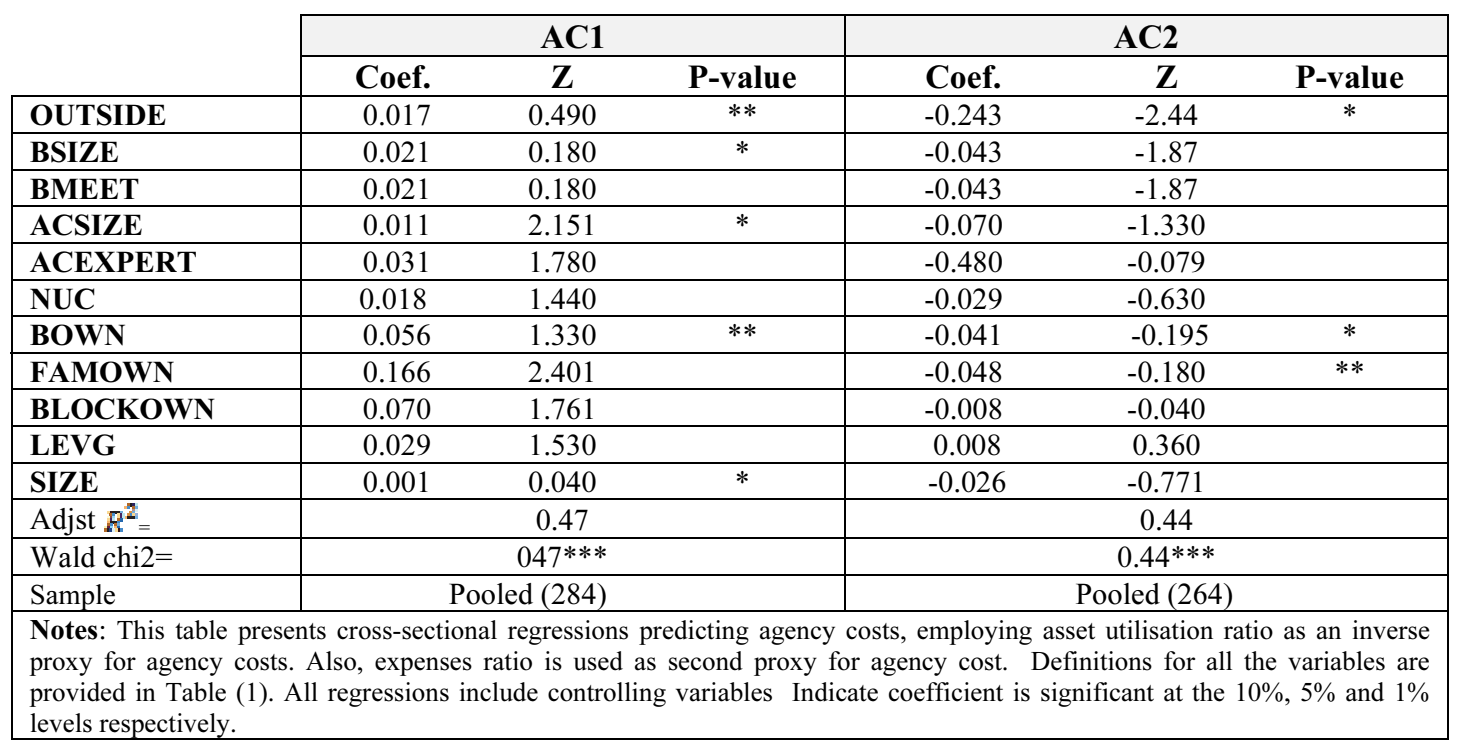


e.g., with a mean of about seven according to Uzun et al (2004) and more than six in Malaysian firms according to Abdul Rahaman and Ali (2006).

Audit committee size averages 3.2 which is slightly larger than in previous years (2007 to 2009) as reported by Alghamdi (2012) and 33\% of Saudi firms have an audit committee possessing at least one financial expert which is smaller than previous years as reported by Alghamdi (2012). In relation to ownership structures, the study sample shows that Saudi listed companies have a mean board ownership of $22 \%$, and a mean family ownership of $47 \%$ and a mean blockholder of ownership of $78 \%$.

Table (2) Descriptive Statistics

\begin{tabular}{|lccccccc}
\multicolumn{1}{l}{ Mean } & Min & Max & Median & $\begin{array}{c}\text { Standard } \\
\text { Deviation }\end{array}$ & Kurtosis & Skewness \\
\hline AC1 & 0.780 & 0.002 & 2.40 & 0.555 & 0.589 & 0.332 & 4.052 \\
\hline AC2 & 0.309 & 0.122 & 0.722 & 0.247 & 0.614 & -1.309 & 3.440 \\
\hline OUTSIDE & 0.710 & 0.54 & 0.830 & 0.670 & 0.580 & -0.939 & 5.711 \\
\hline BRDSIZE & 8.500 & 3.000 & 12,00 & 7.001 & 1.620 & 2.189 & 5.364 \\
\hline BMEET & 4.500 & 3.000 & 10.00 & 4.000 & 1.798 & 0.487 & 2.187 \\
\hline ACSIZE & 3.227 & 3.000 & 6.000 & 3.000 & 0.759 & -0.299 & 4.330 \\
\hline ACEXPERT & 0.333 & 0.333 & 0.500 & 0.300 & 0.622 & -1.200 & 3.413 \\
\hline NUC & 0.640 & 0.000 & 1.000 & 1.000 & 0.576 & -0.799 & 3.655 \\
\hline BOAWONN & 0.220 & 0.050 & 0.890 & 0.089 & 0.433 & 1.800 & 5.221 \\
\hline FAMOWN & 0.470 & 0.000 & 0.950 & 0.340 & 0.543 & -0.895 & 2.899 \\
\hline BLOCKOWN & 0.789 & 0000 & 1.000 & 1.000 & 0.590 & -1.265 & 3.090 \\
\hline LEVG & 0.065 & 0.000 & 0.470 & 0.010 & 0.138 & 1.869 & 5.772 \\
\hline SIZE & 9.330 & 7.690 & 11.44 & 9.442 & 0.687 & 0.777 & 3.197 \\
\hline
\end{tabular}

A correlation coefficient analysis is further performed to examine the relationship between the dependent and independent variables. It is obvious that there is no negative correlation between the independent variables in our model. As indicated, collinearity does not seem to cause concern in the interpretation of regression coefficients of the independent variables in the two models. In relation to standard skewness and kurtosis and as indicated in Tables (2), data is not normally distributed. This is due to the fact that the value of both skewness and kurtosis for some variables indicates high values. Previous studies such as Abdul Rahman and Ali, (2006) suggest that data can be normally distributed if standard skewness is within \pm 1.96 and standard kurtosis is \pm 2 or \pm 3 . Moreover, the variance inflation factor (VIF) for all variables is below 10, showing that multicollinearity is not a serious problem. The mean of VIF for each model is 1.63 and 1.78 respectively. Previous studies confirm that there is no concern with a VIF of less than 10. Therefore, multicollinearity does not constitute an issue in either of the two models. On the other hand, the result of the Hausman test shows insignificant finding as the Chi-2 result is higher than 5\% for both models which led the current study to use random effect. Although the parametric test is a powerful method, requiring rigorous assumptions such as normality and homogeneity (Anderson et al, 2011), a nonparametric test does not require the previous conditions, following the free-distribution 
Table (1) Definitions for Independent and Control Variables

\begin{tabular}{|c|c|c|}
\hline Symbol & Variable name & Description and measure \\
\hline OUTSIDE & Outside directors & The ratio of number of outside directors to total members. \\
\hline BSIZE & Board size & The total number of members on the board. \\
\hline BMEET & Board meetings & The number of meetings held by board of directors. \\
\hline ACSIZE & Audit committee size & The total number of members on the audit committee. \\
\hline ACEXPERT & Expertise & $\begin{array}{l}\text { The ratio of number of financial expertise to total membersin audit } \\
\text { committee. }\end{array}$ \\
\hline NUC & Nomination and remuneration & $\begin{array}{l}\text { A dummy variable that takes the value of } 1 \text { if the firm formulates } \\
\text { this committee, otherwise } 0 .\end{array}$ \\
\hline BOAWONN & Board ownership & Ratio of shares held by directors on the board to total shares. \\
\hline FAMOWN & Family ownership & The percentage of total shares held by specific family. \\
\hline BLOCHOWN & Blockholder ownership & $\begin{array}{l}\text { A dummy variable that takes the value of } 1 \text { if the firm has an } \\
\text { external stockholder owning } 5 \% \text { or more of the outstanding shares, } \\
\text { and } 0 \text { otherwise. }\end{array}$ \\
\hline SIZE & Firm Size & The natural logarithm of total assets at year-end \\
\hline LEV & Leverage & Total debt over total asset \\
\hline
\end{tabular}

\subsection{Model}

The technique used in the study to examine the link between board composition, ownership structure and agency cost employs fixed effects multivariate regression analysis. This technique removes omitted variable bias and allows for controlling unobserved heterogeneity across the sample firms. The model specifications are as follows:

Agency cost $i t(A C)=\alpha+\beta 1(\mathrm{OUTSIDE} i t)+\beta 2(\mathrm{BSIZE} i t)+\beta 3(\mathrm{BMMEET} i t)+\beta 4(\mathrm{ACSIZE} i t)+\beta 5(\mathrm{ACEXPERT} i t)+\beta 6(\mathrm{NUC} i t)+$ $\beta 7($ BOAWON it $)+\beta 8($ FAMOWN it $)+\beta 9($ BLOCHOWN it) $+\beta 10($ SIZE it $)+\beta 11$ (LEV it) $\delta i+\mathrm{e} i t$.

Where:

Agency cost is $(\mathrm{AC})=$ the dependent variable of the study.

$\alpha=$ the intercept

$\delta \mathrm{i}=$ the firm-specific random effect

$e$ it $=$ error term

\section{Test Results}

\subsection{Descriptive statistics}

Table (2) presents descriptive statistics for the variables used in the study's analysis. The average values of asset utilization ratio (AC1) and expenses ratio (AC2) are 0.78 and 0.30 respectively. These results are, to an extent, consistent with prior studies such as Singh and Davidson III (2003) and Gul et al. (2012). Descriptive statistic indicates a high mean representation of outside directors on the board (71\%). These findings emphasise a high compliance rate by Saudi companies with the governance system that recommends that the majority of members of a board of director should be non-executive. Table (2) also shows that the average board size consists of about eight members $($ mean $=8.5)$. In comparison, board size in Saudi Arabia seems to be larger than that in Malaysian firms (e.g., mean size of about five reported by Abdul Rahaman and Ali, 2006) but is slightly smaller than firms in the UK and the US where boards consist of about 9 and 11 respectively as reported by Singh and Davidson III (2003) and Habbash (2010). As indicated in Table (2), the average number of board meetings is about four (mean $=4.0$ ). Board meetings in Saudi Arabia appear to be less frequent than board meetings in US firms 
A final sample comprising 102 companies for three years was selected from the list after excluding several companies that did not meet in the criteria of the study. For example, companies, that did not have complete financial data, complete information on directors, whose annual reports were unavailable, or that were first listed after 31 December 2010, were also excluded. Also, the study excludes all insurance and financial firms from the sample since the accounting standards for income and profit for these firms are significantly different from those of other industries (Ibrahim and Samad, 2011; Campbell and Keys, 2002; Lemmon and Lins, 2001).

\subsection{Dependent Variable (Measuring agency cost).}

The dependent variable of the study is agency cost, which is measured using two alternative proxies: asset utilization ratio, the ratio of total sales to total assets $(\mathrm{AC} 1)$ and expenses ratio as measured by operating expense divided by annual sales (AC2). The asset utilization ratio is an efficiency ratio defined as total sales to total assets, indicating how effectively management deploys a firm's assets (Gul et al. 2012). A low asset utilization ratio may indicate poor investment decisions, insufficient effort, perquisite consumption and purchase of unproductive products. Firms with a low asset utilization ratio are expected to experience high agency costs between managers and shareholders. This proxy was used by prior studies such as Gul et al. (2012); Florackis, (2008); Fleming et al. (2005); Singh and Davidson III (2003); Fleming et al. (2005) and Ang et al. (2000). Following Singh and Davidson III (2003), the second proxy of agency cost is the ratio of selling, general and administrative (SG\&A) expenses to sales (expense ratio). In contrast to asset utilization ratio, expense ratio is a direct proxy of agency costs indicating that a high expense ratio experiences leads to high agency costs (Ibrahim and Samad, 2011; Ang et al., 2000).

\subsection{Independent or Explanatory Variables}

The variables evaluated in this study as potential determinants of agency cost levels can be categorized as representing board characteristics and ownership structure influences. Independent variables which were considered are proportion of outside directors in a board (OUTSIDE), board size (BSIZE), board meetings (BMEETINGS), audit committee size (ACSIZE), financial expertise in audit committee (ACEXPERT), the existence of a nomination and remuneration committee (NUC), the proportion of shares owned by board members (BOAWON), family ownership (FAMOWN) and blockholder ownership (BLOCKOWN). All previous variables are measured, consistent with prior studies such Gul et al. (2012), Ibrahim and Samad (2011), Florackis (2008), Fleming et al. (2005), Singh and Davidson III (2003) and Ang et al., (2000) as shown in Table (1).

Our choice of control variables is motivated by their potential relevance as noted in prior literature such as Ibrahim and Samad, (2011), Wellalage and Locke (2011) and Singh and Davidson III (2003). Several control variables are used to control for companies' characteristics such as firm size and leverage As larger firms are more visible they may face greater scrutiny, therefore firm size is used as a control. Moreover, firm size, measured as the natural logarithm of total assets at year-end, may also depict business diversification in the case of large firms, so asset utilization may improve with size due to scope economies and synergy across difference business lines (Singh and Davidson III, 2003). Leverage is also an important variable as it refers to total debt over total assets of the company, which is considered to be positively related to agency cost. 
shareholders increase the motivation for any shareholder to sustain all of the monitoring costs decreases, since the benefits related to monitoring are proportional to the shareholder's ownership stake. Moreover, Li (1994) found that ownership structure has a significant influence over governance practices. Pagano and Roell (1998) state that optimal dispersion of share ownership can be accomplished by going public which leads to a large percentage of external shareholders who may monitor management closely. McKnight and Weir (2009) also found that ownership structure helps to reduce agency cost.

In line with the findings of previous research, they present evidence that concentrated ownership aligns the interests of managers and shareholders and, hence, reduces agency costs. For example, Shleifer and Vishny (1997) state that ownership structure plays a key role in reducing agency costs by aligning the interests of managers with those of shareholders. Prior studies show mixed findings; for example, based on a sample of NYSE, AMEX, and NASDAQ listed large US corporations, Singh and Davidson III (2003) find that outside block ownership may only have a limited effect on reducing agency costs. Moreover, using a large sample of publiclytraded UK firms over the period 1999-2003, Florackis (2008) concludes that board ownership, managerial compensation and ownership concentration are strongly associated with agency costs. McKnight and Weir (2009), who used three measures of agency costs, state that increasing board ownership also helps to reduce agency costs. Gul et al. (2012) looked at the role of ownership structure and corporate governance in mitigating agency cost in a sample of 50 firms selected on the basis of market capitalization from "Karachi Stock Exchange" during the period 2003 to 2006. They conclude that higher director and institutional ownership reduces the level of agency cost. Wellalage and Locke (2011), based on eleven years of data for 100 unlisted small businesses, show that ownership concentration is the most significant. In general, the structure of ownership is arguably a key factor in reducing agency cost; hence, the next hypotheses are as follows:

H8: A greater percentage of board ownership should reduce agency cost.

H9: A greater percentage of family ownership should reduce agency cost.

H10: A greater percentage of blockholder ownership should agency cost.

\section{Research Methodology 3.1 Sample selection}

For the empirical analysis of agency costs, this study utilizes a sample of publicly-traded Saudi firms over the period 2010-2012. One of the greatest challenges of this study has been the difficulty in obtaining relevant and available information. Using secondary data regarding board composition and ownership structure required downloading the annual reports for each company and collecting each item individually. In other words, this information was obtained manually by calculating the ratios or numbers for governance items or financial items. All companies listed on the Saudi stock market (formerly known as Tadual) as of December 31, 2010 were selected as a sample for the study. Data not available in the Saudi market was gathered from the homepages of these companies as well as through personal communications.

A total of 161 companies were listed on the Saudi stock market (Tadual) at the end of 2010. As a longitudinal study, it is important to ensure that all firms were active for the entire period of the research. Therefore, this study implements non-probability sampling by employing the judgment method to select sample members to fit certain criteria (Ibrahim and Samad, 2011; Cooper and Schindler, 2001). 
directors. For example, Xie et al. (2003) and Sarkar et al. (2006) confirm that frequency of board meetings is associated with reduced levels of agency cost.

Audit committees might be responsible for alleviating the agency problem between the firm and its outside shareholders by monitoring its financial reporting. In other words, agency theory expects the audit committee to monitor and oversee the integrity of financial reporting (Xie et al., 2003). Thus, much emphasis has been placed on the fact that the audit committee's role is to prevent irregular fraudulent accounting statements (Klein, 2002). In Saudi Arabia, the audit committee is a committee appointed by a company which includes three members or more, at least one of whom should be a specialist in financial affairs. The pivotal role of the audit committee is to enhance communication and mitigate conflict between the external auditor and management. Moreover, it is expected to mitigate the agency cost by monitoring managerial behaviour and providing the external auditor with the necessary information. Prior studies such as Lin et al. (2006); Bedard et al. (2004); Xie et al. (2003) and Klein, (2002) find that the audit committee plays a significant role in mitigating agency problems.

Another specific governance mechanism is the setting up of a nomination and remuneration committee. The adoption of this committee, which became a compulsory mechanism at the beginning of 2010 in Saudi listed companies, has been much slower than other committees such as the audit and executive committee. The nomination and remuneration committee's key function is to provide recommendations to the board concerning the appointment of members to the board and reviewing and ensuring the requirements of appropriate skills for membership of the board including qualifications, experience, and independence and, finally, to establish clear policies regarding indemnities and remunerations of board members and top executives. An effective nomination and remuneration committee should therefore ensure the appointment of nonexecutive directors whose interests are aligned with those of the shareholders and so help reduce agency costs. Hence, previous empirical findings seem to suggest that effective governance with a well-structured board and sub-committees will reduce agency cost, thus leading this study to the following hypotheses:

H1: A greater percentage of outside directors on the board should reduce agency cost.

H2: A larger board of directors should reduce agency cost.

H3: Frequent board meetings should reduce agency cost.

H4: Larger audit committee size should reduce agency cost.

H5: A greater percentage of financial expertise on the audit committee should reduce agency cost.

H6: The existence of a nomination and remuneration committee should reduce agency cost.

Ownership structure is also considered as an internal or external monitoring mechanism which seems to play an important role in mitigating agency costs. Most studies in accounting and economics have highlighted that corporate ownership structure decisions reflect attempts to reduce agency problems between different stakeholders (Jensen and Meckling, 1976). In other words, corporate ownership is set to increase a firm's value, accounting for potential conflicts of interest between a controlling shareholder and minority shareholders. Gogineni et al. (2010) found that agency costs rise as firms move from a single owner/single manager ownership structure to more complicated ownership structures and suggest that agency costs are significantly higher when firms are not managed by owners. This idea is consistent with Holderness (2007) who argues that as the number and kinds of 
main objective of these mechanisms is to align the goals of owners with those of management. Board composition is an internal mechanism strategy used to monitor management and reduce agency costs. MacMillan and Downing (1999) state that governance system has become compulsory for a firm to perform competitively as well as in promoting a firm's entrance to the international capital market. Therefore, there is a need to apply good governance that is induced by the market.

Fama and Jensen (1983) argue that a system that can separate decision management from decision control is needed in order to limit agency costs. Core et al. (1999) suggest that there are greater agency issues in listed US firms with weaker governance mechanisms; therefore, governance mechanisms can introduce a desirable system that may limit the power of managers to disregard the interests of shareholders, thereby decreasing agency costs. Accordingly, a large number of studies such as Gul at al. (2012), Wellalage and Locke (2011), Singh and Davidson III (2003) and Fama and Jensen (1983) argue that governance system reduces agency cost.

Board governance mechanisms have been the focus of a number of studies world-wide. In Saudi Arabia, firms are expected to adopt board structures consistent with the Combined Code. As a condition of being listed on the Saudi stock exchange, companies must provide a statement in their annual reports about the ways in which they apply the principles expressed in the Code of corporate governance . Having outside directors on the board is perceived as a monitory mechanism which can play an important role in limiting or controlling the agency problem. There are numerous studies in the literature which focus on the role of outside directors and suggest that they are more likely to work in the shareholders interest; these include Gul et al. (2012), Singh and Davidson III (2003), Westphal and Zaiac (1995), Brickley et al. (1994) and Byrd and Hickman (1992).
Similar results were found by McKnight and Mira (2003) and Henry (2010 and 2004) concluding that agency costs will be lower the higher the number of outside directors on the board. On the other hand, the findings of Agrawal and Knoeber (1996) and Hermalin and Weisbach (1991) conclude that a higher percentage of outside directors on the board does not play a significant role in reducing agency costs. Ang et al. (2000) also support the argument of Hermalin Agrawal and Knoeber (1996) and Weisbach (1991).

Large boards were also found to be more powerful and effective than smaller ones in a study by Pearce and Zahra (1991). This finding is also supported by Singh and Davidson III (2003) who suggest that the association between size of the board and asset utilization ratio is positive and statistically significant. Furthermore, they find that agency costs will be lower if there is greater asset utilization ratio. In contrast, Florackis and Ozkan (2004) in a study carried out between 1999 and 2003 on a sample of UK public listed companies, conclude that size of board has a negative influence on agency cost proxy asset turnover, which means that the larger size of the board may increase agency costs because of less efficiency.

While no specific number of meetings is mandated by the Saudi Code of Corporate Governance, members of boards of directors should meet at least four times a year in order to endorse their quarterly financial statements (Alghamdi, 2012). The number of meetings has been employed in prior studies as an indicator of a board's diligence, since inactive boards are less likely to monitor management effectively. It is argued that directors on boards that meet frequently are more likely to discharge their duties in line with shareholders' interests since more time can be devoted to controlling issues such as wrongdoing, conflicts of interest and monitoring management (Habbash, 2010). Generally, few studies have paid heed to board meetings as a key characteristic of the board of 
and Yatim et al. (2006) argue that most research into monitoring mechanisms has been conducted in developed countries and very little in developing countries. Therefore, this paper provides a fundamental contribution to the agency costs debate by presenting new evidence from Saudi Arabia which has different characteristics in ownership structure. Moreover, the findings of this paper could be useful to Saudi firms, regulators and legislators in their attempts to enhance the quality of monitoring mechanisms.

The following section provides a review of prior studies and the development of hypotheses and is followed by methodology, data variables and procedures used for this empirical study. The conclusions, limitations and recommendations are then discussed. Finally, suggested future research is provided.

\section{Literature Review and Development of Hypotheses}

The separation of ownership from management does not come without costs (Depken at al., 2006). Agency costs can manifest in various forms, including monitoring costs, bonding costs, and residual costs. Hoque (2006) and Deegan et al. (2000) define monitoring costs as the costs which stem from the agent's monitoring behaviour, such as corporate governance structure cost, external auditing cost or any action which might curb opportunistic behaviour. In addition, they describe bonding costs as the costs which are associated with aligning the agent's interest with the principal's interest, such as compensation or any reward structure that mitigates opportunistic behaviour (Shapiro, 2005). In other words, managers bond themselves to prepare for financial reporting. Residual costs are defined as all costs incurred as a result of a conflict between the agent's and the principal's interests other than bonding and monitoring cost. Clearly, the residual costs stem from inequality between the monitoring cost and bonding cost (Denis et al., 1997).

Agency problems are mitigated by a number of actions that include monitoring behaviour or even supplying a catalyst to boost the behaviour toward owners' interests (Shapiro, 2005). Principals can protect their interests by establishing appropriate incentives for the agents and by incurring monitoring costs designed to limit the irregular activities of agents. Board structure and ownership concentration have been suggested as a potential incentive mechanism to help align the interests of managers with those of shareholders (Gul et al., 2012; Singh and Davidson III, 2003).

In Saudi Arabia, the agency costs of listed companies may result from conflicts between owner-manager relationships. However, the agency costs may also come from the conflict between the minority and the majority of shareholders (Aghamdi, 2012). There is no clear evidence concerning the issues of agency relationship in the Saudi environment because of the shortage of studies in this area and because of the modern emergence of governance mechanisms. It could be argued that conflicts of agency relationship may be fewer and weaker in developing countries such as Saudi Arabia between the principals and agents. According to Clark (2004) collectivism is a dimension of the relationship between principals and agents in Asia, South America and Southern Europe. However, the conflict between the majority of shareholders and the minority can be made stronger.

The accounting literature shows many techniques by which agency conflict can be minimised in order to reduce agency costs. These techniques might be identified between internal mechanisms such as compensation contracts, bonding costs, monitoring activities and external mechanisms such as monitoring activities by a capital market authority, regulator or external audit (Shapiro, 2005). The 


\section{I- Introduction}

Previous studies such as Gul et al. (2012), Wellalage and Locke (2011) and Singh and Davidson III (2003) provide evidence on board composition and agency costs measured in terms of asset utilization and operating expenses. The focus of these studies has been the impact of the governance system on expected agency costs. Their assumption is that concentrated ownership and strong board structure can help reduce the magnitude of these costs and their negative impact on firm value.

Agency costs come from the misalignment of the interests of the owners and managers of firms when the separation of ownership and control occurs (Jensen, 1986). According to Core et al. (1999) firms may confront higher issues of agency cost when they have a weak board structure and, rather than maximizing the firm's value, managers of such firms overindulge in personal pursuits. The agency model identifies a number of governance mechanisms which realign the interests of agents and principals and so reduce agency costs. Recent changes have taken place in Saudi Arabia; for example, the Saudi Capital Market Authority has stressed the importance of a governance system that takes a specific form. In this case, Saudi firms are expected to adopt a board composition structure with a Combined Code of best practice.

According to the Code, the board of directors should carry out many functions and represent the shareholders, so the ultimate responsibility for the firm rests with the board of directors, even if a company sets up committees or delegates some of its powers to a third party (Alghamdi, 2012). Therefore, an active board is generally deemed to be interested in contributing to owners' rights and benefits and, through strategic policies, enhancing performance and creating wealth (Wellalage and Locke, 2011) leading to decreased agency costs.
Agency costs will also be reduced by higher ownership concentration. Singh and Davidson III (2003) also support the prediction of agency theory however they find little evidence that the agency problem is minimized by increasing ownership concentration in a firm. Saudi Arabia is characterised by family controlled firms or family ownership which is the most common form of Saudi business organization (Alghamdi, 2012). This may be a cause of decreased agency cost because when ownership concentration is increased it could result in a convergence of interests between company managers and shareholders as suggested by Jensen and Meckling (1976) in the agency theory.

Board composition and ownership structure are currently an important issue which attracts considerable attention from academic researchers (Gul et al., 2012). Numerous studies have found there to be a significant impact by board characteristics and ownership structure on agency cost. For example Gul et al. (2012), Ibrahim and Samad (2011), Wellalage and Locke (2011), Florackis, (2008) and Coles et al. (2005) argue that an active board and concentrated ownership contribute to reduced agency costs. However, a study presented by McKnight and Weir (2009) concludes that the board has no effect on agency costs.

The objective of this study is to extend the investigation into the role of board structure and structure of ownership in minimizing agency cost by providing new evidence from Saudi Arabia. Following prior studies such as Gul et al. (2012), Singh and Davidson III (2003) and Wellalage and Locke (2011), it uses the proxies of agency costs: asset utilization ratio and operating expenses ratio. This research is motivated by several considerations as follows: First, to the best of the author's knowledge, it is the first study undertaken in Saudi Arabia to investigate the role of board composition and ownership structure in minimizing agency cost. Carcello et al. (2006) 


\title{
Do Board Composition and Ownership Structure Mitigate Agency Cost: Evidence from Listed Saudi Firms
}

\author{
Salim Ali L. Alghamdi \\ Accounting Dept. Taif University - Saudi Arabia
}

\begin{abstract}
This study aims to investigate the effectiveness of board composition and concentrated ownership in reducing agency cost among firms listed on the Saudi market over the period 2010-2012. It employs two measures of agency cost: the ratio of assets utilization and operating expenses ratio. By employing inductive approach, multivariate random effect regression is used to analyze the data. Findings reveal that a higher percentage of outside directors seem to be effective in reducing agency cost. Moreover, a larger board and audit committee size serve the same role but, frequent meetings by board directors, the existence of a nomination and remuneration committee and financial expertise in audit committee do not appear to protect the firm from agency cost. The study also provides evidence that concentrated ownership including board ownership and family ownership reduce the level of agency cost while blockholder ownership has no effect. These results are consistent with agency theory, which predicts that a beneficial governance system and concentrated ownership mitigate agency cost. This paper provides a fundamental contribution to the agency costs debate by presenting new evidence from Saudi Arabia which has different characteristics in ownership structure. These findings also could be helpful for Saudi regulators in their attempts to enhance the quality of monitoring mechanisms and reduce agency cost. This study does not take endogeneity test in consideration.
\end{abstract}

Keywords: Board Composition, Ownership structure, Agency cost, and Saudi Arabia

Paper type: Research paper

All rights reserved. 